\title{
Field assessment of surge and continuous furrow irrigation methods in relation to tillage systems
}

\author{
Mohamed A. Mattar ${ }^{1,2 *}$, Mohamed A. El-Saadawy ${ }^{2}$,Mamdouh A. Helmy ${ }^{3}$, and Hussien M. Sorour ${ }^{3}$ \\ ${ }^{1}$ Department of Agricultural Engineering, College of Food and Agriculture Sciences, King Saud University, \\ P.O. Box 2460, Riyadh 11451, Saudi Arabia \\ ${ }^{2}$ Agricultural Engineering Research Institute (AEnRI), Agricultural Research Center, P.O. Box 256, Giza, Egypt \\ ${ }^{3}$ Department of Agricultural Engineering, College of Agriculture, Kafr El-Sheikh University, Egypt
}

Received April 11, 2016; accepted January 3, 2017

\begin{abstract}
A b s t r a c t. Surge flow irrigation is one of the irrigation techniques for controlling furrow irrigation. The aim of this study was to investigate the effect of surge furrow irrigation on water management compared with continuous irrigation for different tillage systems. An experimental field was treated with various tillage systems (mouldboard plough, chisel plough and rotary plough) and water irrigation application methods (continuous flow, control) in which irrigation water was applied continuously, and surge flow (3-surges, 4-surges and 5-surges) in which irrigation water was applied intermittently until it reached the tail end of the furrow. The results showed that water savings obtained using the surge technique were $18.58,11.84$ and $18.93 \%$ lower water use than with continuous flow, for the mouldboard, chisel and rotary ploughs, respectively. The 3 -surges treatment with the rotary plough reduced the advance time by $25.36 \%$ from that for continuous irrigation. The 4-surges treatment with the mouldboard plough had the highest water application efficiency $(88.13 \%)$. The 3-surges treatment with the rotary plough had the highest distribution uniformity $(85.01 \%)$. The rotary plough did not cause as much soil aeration around the root system as the other tillage systems. The field research provided information about surge flow, aimed at reducing advance times and increasing irrigation efficiency.

K e y w o r d s: irrigation, ploughing system, water application efficiency, distribution uniformity, advance rate
\end{abstract}

\section{INTRODUCTION}

Surface irrigation is the oldest method of irrigation. It is practiced by flooding the soil surface (border and basin irrigation) or by running water into small ditches (furrows). Surge flow irrigation is considered as a means to improve surface irrigation systems (Cholpankulov et al., 2005; Horst, 2007; Jalali-Farahani et al., 1998; Trout, 1991). The surge application of water to surface irrigation systems is

\footnotetext{
*Corresponding author e-mail: dr.mohamedmattar@gmail.com
}

distinctly different from either sprinkle or trickle systems. Bishop et al. (1981) defined surge flow irrigation as the intermittent application of irrigation water to a furrow or border, creating a series of on and off conditions of constant or variable time spans at the furrow inlet. The cycle time is the time between the beginning of one surge and the beginning of the next.

The surge water applications lead to a discontinuity in the infiltration process. The result is often a reduction in surface layer permeability. However, this effect widely varies depending on soil compaction and its prior wetting history, surface water velocities, and the duration of the on/off cycles (Stringham and Keller, 1979). The two basic phenomena which affect infiltration that takes place during the intermittent off-time of surge flow irrigation are the redistribution of infiltration water in the soil profile and particle sealing of the wetted soil surface (Samani et al., 1985). Kemper et al. (1988) showed that the mechanisms causing the infiltration reduction in surge irrigation include consolidation of soil in the furrow beds and sealing of the furrow during the interruption of the flow. Trout (1991) found that surface seal formation reduces infiltration by about $50 \%$. Kanber (2001) showed that surge flow reduced the water infiltration of surface soil loosened by ploughing by $13-23 \%$ when compared with continuous flow, thus establishing an unrivalled advantage for level-furrow systems.

Many authors and investigators (Eid, 1998; El-Zaher et al., 1996; Horst et al., 2007; Kifle et al., 2008; Wang et al., 2005) have summarised the potential benefits of using surge rather than continuous irrigation. Bishop et al. (1981) reported that in a surge furrow irrigation experiment with cycle times of $2,5,10$, and $20 \mathrm{~min}$ and with a cycle

(C) 2017 Institute of Agrophysics, Polish Academy of Sciences 
ratio of 0.5 and a discharge rate of $1.261 \mathrm{~s}^{-1}$, surge flow irrigation was more effective during the first irrigation than in the second one. Izuno et al. (1985) noted that continuous irrigation advance required from 1.6 to 3.6 times as much water as that required for surge flow irrigation in the furrows. Testezlaf et al. (1987) showed that, by controlling the on-off cycle and the flow rate, surge flow could lead to decreased deep percolation and run off at the lower end of the field. Purkey and Wallender (1989) reported that surge irrigation reduced infiltration depths along the furrow compared with continuous flow treatments. Ismail et al. (1985) designed an automatic drop gate device to control water. They reported that the surge flow treatments showed a higher distribution uniformity, which indicates that the depth of water infiltration was more uniform than for continuous flow. Surge flow irrigation also had a higher potential application efficiency than continuous irrigation under the same inflow, meaning that surge flow used less water (El-Zaher et al., 1996; Ismail et al., 1985; Osman, 1991). Eid (1998) showed that the increases in corn grain yield under a surge flow treatment with a 0.5 cycle ratio were $14.1-15 \%$ above the yield of the continuous irrigation, and this treatment also had the highest water utilisation efficiency values of $1.52-1.22 \mathrm{~kg} \mathrm{~m}^{-3}$. Wang et al. (2005) showed that surge irrigation with sediment-laden water can save irrigation water and improve irrigation quality. Horst et al. (2007) observed that the best irrigation water productivity was achieved with surge flow on alternate furrows, which reduced irrigation water use by $44 \%$ and led to high application efficiency (85\%). Kifle et al. (2008) reported that surge flow treatment with lower discharge rates and a lower cycle ratio performed better in reaching the tail end of the furrow, with an advance time $23 \%$ faster than a comparable continuous flow.

The bulk density of a soil influences soil strength for structural purposes and for traffic-support of vehicles, animals, and humans. It affects plant growth, water infiltration into soil and drainage from soil, power required to till soil, and performance of tillage tools. Suliman et al. (1993) indicated that tillage treatments decreased the values of bulk density below the corresponding value from a no-tillage treatment. They found that the treatment with a chisel plough (one pass) is the most effective treatment in terms of the total porosity. Taieb (1998) reported that soil bulk density was decreased after tillage operations. The reduction was greater when the ploughing depth was $5 \mathrm{~cm}$ and less reduction was found when the ploughing depth was $20 \mathrm{~cm}$. El-Beily (1995) reported that the minimum values of moisture content were obtained after ploughing operations in soils treated by a rotary plough. El-Gohary et al. (1988) reported that after using a mouldboard plough, a higher infiltration rate was found than after using a chisel plough.

Shortages of water have become one of the principal causes of poverty and starvation in the world. Irrigation is vital to ensure essential moisture for plant growth. However, to the best of our knowledge, no previous research has studied the effects of surge flow and tillage methods on irrigation performance.

Therefore, the objectives of the present study are to:

- investigate the infiltration behaviour for surge flow irrigation compared with conventional continuous flow under different tillage systems;

- study the effect of surge flow irrigation on water advance times and water savings for different tillage systems; and - select the best on-off times for a surge flow irrigation system.

\section{MATERIALS AND METHODS}

The experimental area was divided into three large plots with three replications of each plot; each plot was $17 \mathrm{~m}$ wide and $95 \mathrm{~m}$ long. Each plot was divided into 4 strips. Each strip was used for a specific treatment. The area of each strip was $332.5 \mathrm{~m}^{2}$. Each treatment involved 5 furrows; the first, the third, and the fifth were identically irrigated; the second and fourth were non-irrigated furrows. Buffer furrows (1 m spacing) separated the treatments. The soil type was clay loam soil (32.5\% sand, $37.5 \%$ silt and $30 \%$ clay). The test was conducted on $95 \mathrm{~m}$ long furrows having a slope of $0.04 \%$. Manning roughness coefficient (n) was calculated from field observations of the furrow cross-sectional area, flow rates, flow water depths and water surface width (Horst et al., 2005). The value of $n$ was 0.037 . The furrow spacing was designed to be $0.70 \mathrm{~m}$. Stakes were placed at regular intervals $(10 \mathrm{~m})$ along each furrow up to $80 \mathrm{~m}$ from the furrow inlet. The furrows were irrigated alternately with different tillage systems. The inflow rate was constant over the irrigation period in all treatments. The water was applied in pulses until it reached the tail end of the furrow.

Two factors, ie plough and irrigation, were studied and tested in this work. The three ploughing treatments were a mouldboard plough with an optimum ploughing depth of $25 \mathrm{~cm}$, a chisel plough with an optimum ploughing depth of $20 \mathrm{~cm}$, and a rotary plough with an optimum ploughing depth of $12 \mathrm{~cm}$. The four irrigation treatments were continuous flow (control); 3-surges irrigation with on-times of 10,19 , and $25 \mathrm{~min}$, and an off-time of $20 \mathrm{~min}$ between the surges; 4-surges irrigation with on-times of $6 \mathrm{~min}, 11,15$, and $18 \mathrm{~min}$ and an off-time of $15 \mathrm{~min}$ between the surges; 5 -surges irrigation with on-times of 4, 8, 10, 12, and $13 \mathrm{~min}$ and an off-time of $10 \mathrm{~min}$ between the surges. Twelve treatments were evaluated in cornfields.

The on-time factor $(O T F)$ and on-time cycle $(O T C)$ were determined according to Younts et al. (1996), as follows:

$$
\begin{gathered}
\text { OTF }=[C N]^{1.52}-[C N-1]^{1.52}, \\
\text { OTC }=\text { OTF OTC },
\end{gathered}
$$


where: $C N$ is cycle number, and $O T C_{1}$ is on-time for the first cycle.

A three bottom mouldboard plough was used. It was composed of three bottoms fixed on a $60 \mathrm{~cm}$ high frame and manufactured from a square cross section of $10.16 \mathrm{~cm}$ width with a thickness of $6 \mathrm{~mm}$. The bottom was $50 \mathrm{~cm}$ tall and had a net cutting width of $35 \mathrm{~cm}$; the total cutting width of the plough was $105 \mathrm{~cm}$. The plough mass was approximately $600 \mathrm{~kg}$.

A seven share chisel plough was used. It was composed of three rows with $50 \mathrm{~m}$ spacing between the rows. The shares were distributed in rows of 2, 2 and 3 from front to rear with a $50 \mathrm{~cm}$ spacing between shares in the same row. The share beam height was $50 \mathrm{~cm}$. The plough mass was approximately $400 \mathrm{~kg}$.

The working width of the rotary plough was $190 \mathrm{~cm}$. The distance between flanges was $25 \mathrm{~cm}$. The length of the adjustable rear shield was $195 \mathrm{~cm}$ and the width was $50 \mathrm{~cm}$. The diameter of the rotor shaft was $7.64 \mathrm{~cm}$. The depth shoe was present to adjust the depth of the cut.

A blocked furrow infiltrometer was used to measure the infiltration rate of the soil in the field. The experiments were conducted to measure the water infiltration rates under continuous and surge applications of water. Water was applied to the top of the soil to maintain a constant water level. This level was recorded. For example, after one minute a certain volume of water infiltrated the soil, the new level of water was recorded and the difference between the readings gave the volume of water which infiltrated the soil during the specified time interval. The volumes of water infiltrated at different time increments were measured during the on-time. When the off-time began, the depth of water above the soil was drained. This process was repeated for each cycle time specified for each treatment. The water infiltration depths in the soil, which were recorded against time, were used to calculate the parameters in the infiltration equations for each on-time. The simplest and most commonly used approximation for infiltration is the Kostiakov equation which can be written in general terms for furrow irrigation as (Walker et al., 2006):

$$
Z=k T^{a},
$$

where: $Z$ is cumulative infiltration ( $\mathrm{mm}), T$ is elapsed time of infiltration (min), $k$ and $a$ are empirical coefficients, $k$ has units of $\mathrm{mm} \mathrm{min}^{-\mathrm{a}}$.

Inflow rates were measured by calibrated siphon tubes. The siphon tubes were $2 \mathrm{~m}$ in length and $50 \mathrm{~mm}$ in diameter. The siphon tubes were calibrated using a bucket and a stopwatch while collecting a constant volume of water which was delivered from the siphon at different times. This calibration was repeated many times. The rate of discharge used in this study was $1.51 \mathrm{~s}^{-1}$ for each furrow.
The water advance and recession times were recorded at ten points along each furrow. These points were called stations. The on-off cycle time was controlled with a stopwatch. The time needed for water to advance through the entire furrow was recorded and irrigation was terminated.

All of the advance data were fitted to a power function of the following form to represent the relationship between time and the distance that water has advanced across the furrow. The approach of James (1993):

$$
x=p t^{r}
$$

was used, where: $x$ is the distance that water has advanced across the furrow $(\mathrm{m}) ; t$ is time since the start of advance (min), and $p$ and $r$ are fitted parameters.

Furrow irrigation performance indicators are water application efficiency $\left(E_{a}\right)$ and distribution uniformity $(D U)$. $E_{a}$ is a management performance indicator and $D U$ characterises the irrigation system (ASABE, 2003).

Water application efficiency $\left(E_{a}\right)$ was calculated according to Walker (1989) as follows:

$$
E_{a}=\frac{W_{s}}{W_{f}} 100,
$$

where: $W_{s}$ is water stored in the root zone of the plants (corn root zone depth is $60 \mathrm{~cm}$ ) and $W_{f}$ is water delivered to each treatment.

Distribution uniformity $(D U)$ was determined as defined by Micheal (1978) as follows:

$$
D U=\left(1-\frac{y}{d}\right) 100
$$

where: $d$ is the average depth of water stored along the run during the irrigation and $y$ is the average numerical deviation from $\bar{d}$.

Data of the present study were subjected to analysis of variance (ANOVA) in a randomised complete block design using CoStat (Version 6.303, CoHort, USA, 1998-2004). Least significant differences (LSD) tests, at $p \leq 0.05$, were applied to compare the means of measured parameters.

\section{RESULTS AND DISCUSSION}

The relation between cumulative infiltration and infiltration opportunity time for the three plough treatments under continuous flow is shown in Fig .1. At the same time, the Figure shows the relation between infiltration rate and infiltration opportunity time. The highest cumulative infiltrated water and infiltration rate at any time was achieved by mouldboard ploughing rather than using the chisel and rotary types. This may be due to the lowest bulk density $\left(1.11 \mathrm{~g} \mathrm{~cm}^{-3}\right)$ and the highest total porosity $(58.11 \%)$ associated with the mouldboard plough, while the rotary plough caused the highest bulk density $\left(1.25 \mathrm{~g} \mathrm{~cm}^{-3}\right)$ and the lowest total porosity $(52.83 \%)$. For each plough treatment, infiltration rates were the highest when the soil was relatively dry, then dropped to a much lower rate after a period of 


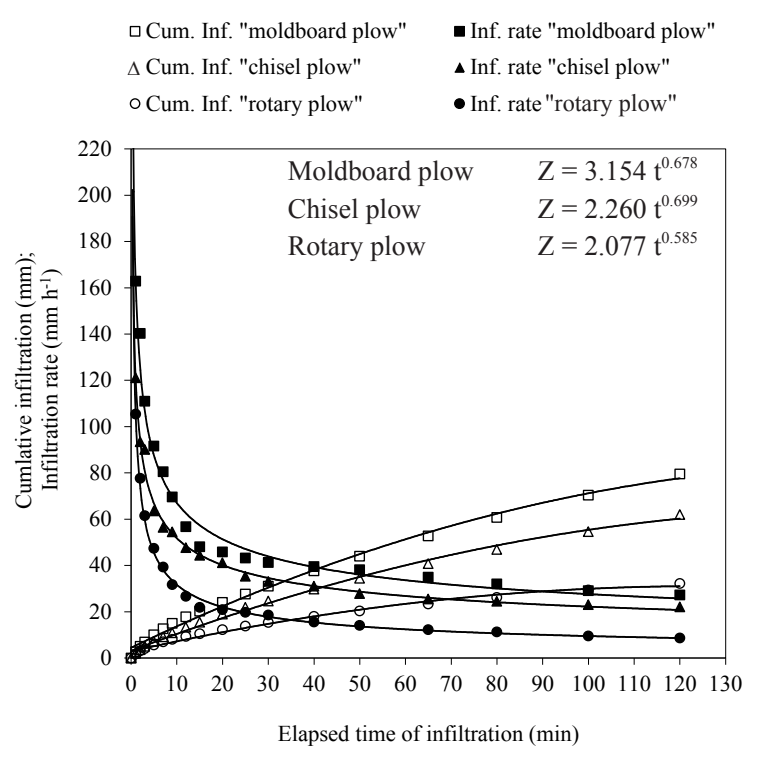

Fig. 1. Cumulative infiltration and infiltration rate vs. elapsed time of infiltration for continuous flow under three different plow conditions.

time, then became lower and almost constant after more time, as the soil became saturated with water. The sealing of the soil surface and the formation of soil crusts, which are important elements in reducing high infiltration rates, are caused partly by wetting and subsequent drying of the soil. The Kostiakov equation was fitted to the cumulative infiltration data from the continuous flow treatment for different plough systems as presented in Fig. 1.

Contrasting the surge flow treatments with the continuous flow treatment under different plough conditions, the infiltration rate is plotted against elapsed time (excluding the surge off-time) in Figs 2 to 4. As shown in Fig. 2, the infiltration rate starts high at $215.9,175.7$ and $116.1 \mathrm{~mm}$ $\mathrm{h}^{-1}$, and drops to $61.2,51.7$ and $29.2 \mathrm{~mm} \mathrm{~h}^{-1}$ after $10 \mathrm{~min}$ of on-time for the 3-surges treatment under the mouldboard, chisel and rotary ploughs, respectively. For the 4-surges treatment, the infiltration rate starts high at 222.6, 191.3 and $125.7 \mathrm{~mm} \mathrm{~h}^{-1}$, and drops to $70.5,56.5$ and $35.3 \mathrm{~mm} \mathrm{~h}^{-1}$ after $6 \mathrm{~min}$ under the mouldboard, chisel, and rotary ploughs, respectively, as shown in Fig. 3. Similarly, the values for the 5-surges treatment start high, at 266, 226 and $111.8 \mathrm{~mm} \mathrm{~h}^{-1}$, and drop to $84.5,70.6$ and $52.2 \mathrm{~mm} \mathrm{~h}^{-1}$ after 4 min under the mouldboard, chisel and rotary ploughs, respectively, as shown in Fig. 4.

A rebound or jump phenomenon occurs, where the initial infiltration rate following the off-time is higher than the infiltration rate measured at the end of the preceding surge. This initial rate even exceeds the infiltration rate shown for continuous flow at the same opportunity time. As the surge cycle proceeds, however, the infiltration rate rapidly declines. The rebound effect is evident across all three ploughs and all three surge flow treatments, as shown in Figs 2 to 4 . The figures indicate that the 3-, 4- and 5-surges

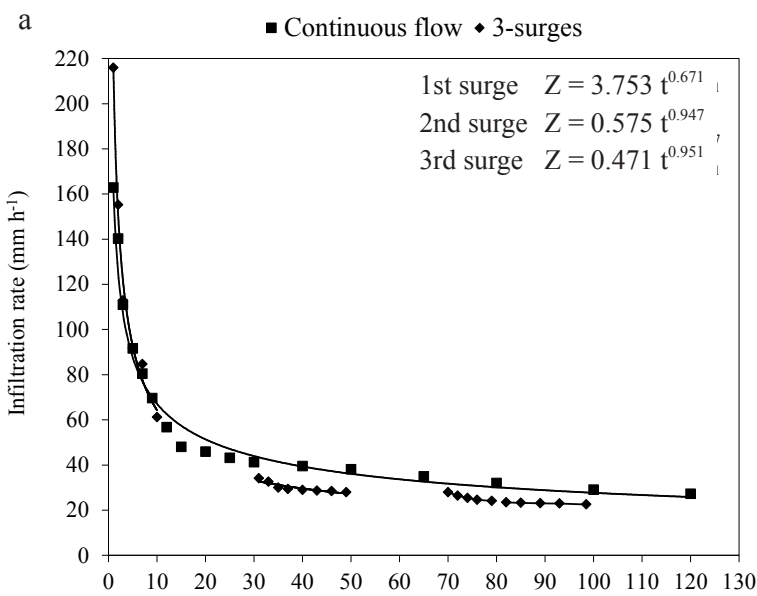

b

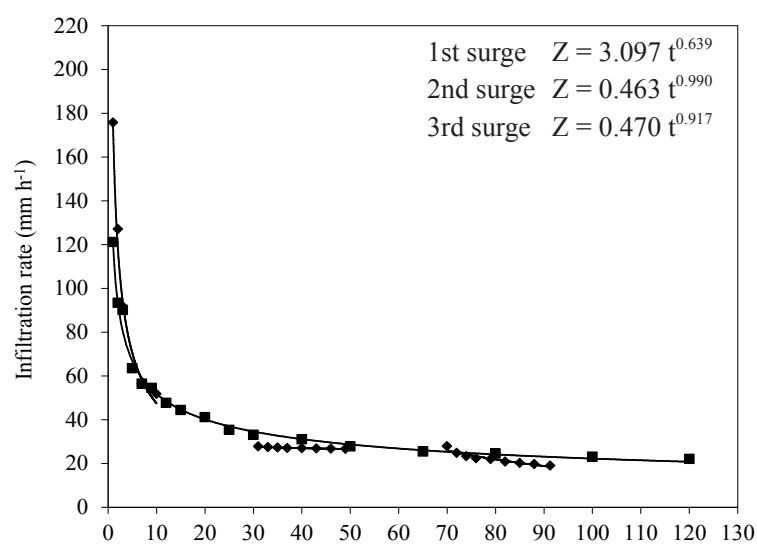

c

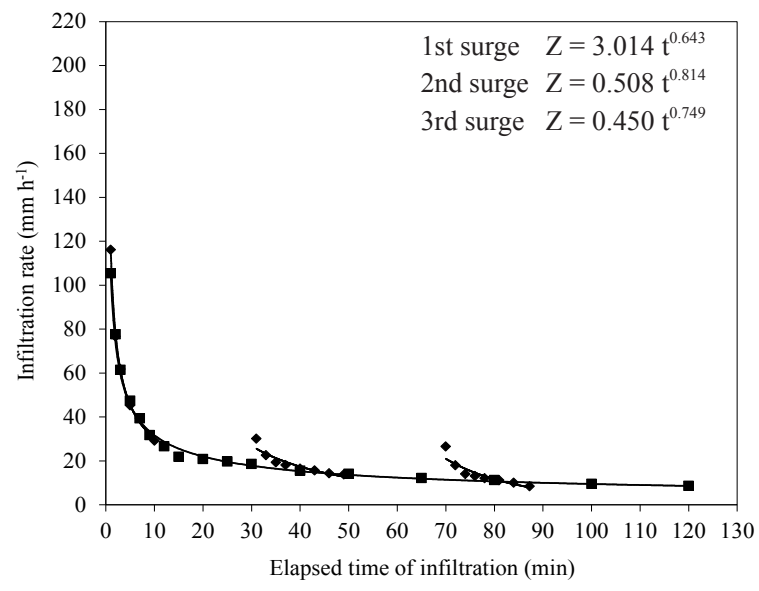

Fig. 2. Comparison of infiltration rates for 3-surges and continuous flow under: $\mathrm{a}$ - moldboard plow, $\mathrm{b}$ - chisel plow, c - rotary plow. 


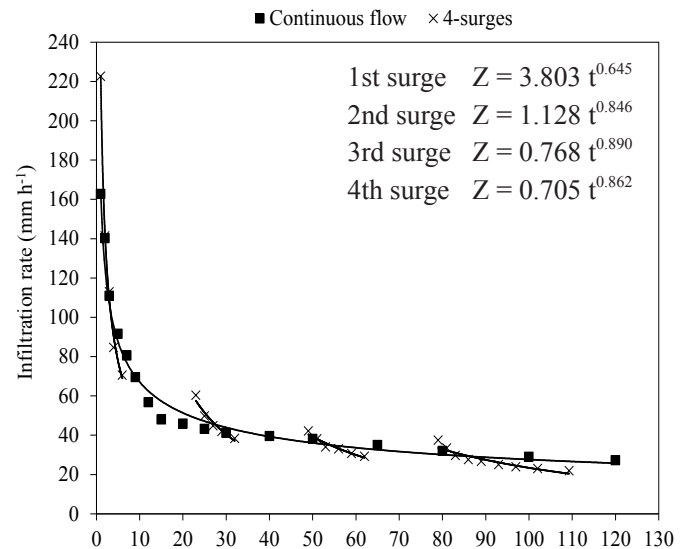

b

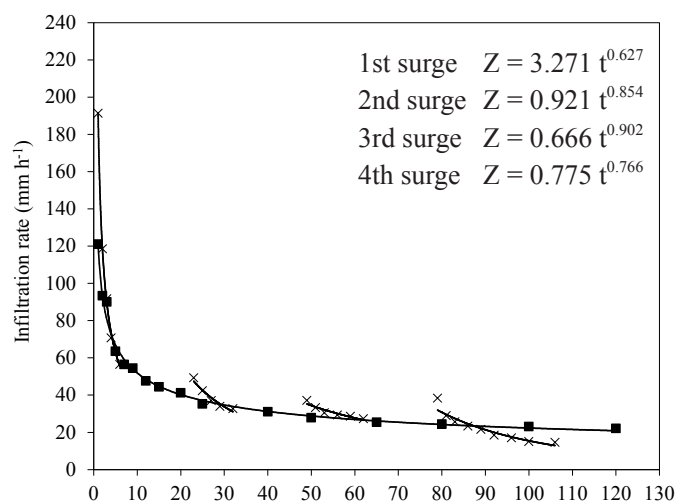

c

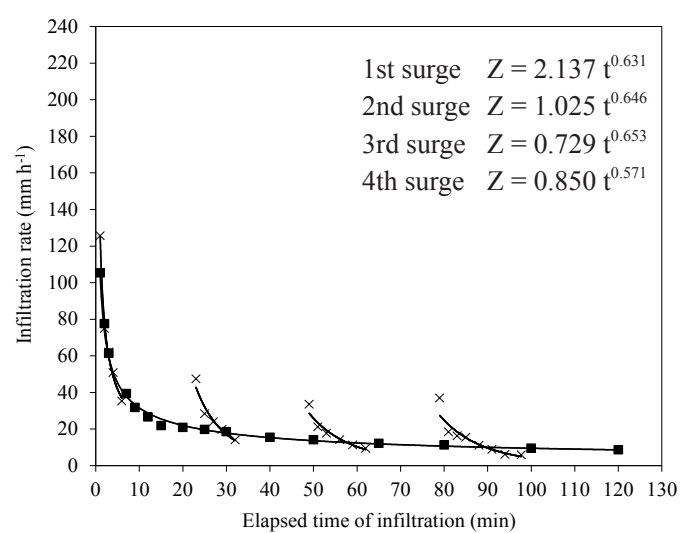

Fig. 3. Comparison of infiltration rates for 4-surges and continuous flow under: $\mathrm{a}$ - moldboard plow, $\mathrm{b}$ - chisel plow, $\mathrm{c}$ - rotary plow.

treatments reduced the quasi-steady infiltration rate by $17.30,19.54$ and $27.10 \% ; 14.20,33.88$, and $35.22 \%$; and 2.34, 31.94 and $46.63 \%$ compared with the continuous flow treatment when using the mouldboard, chisel and rotary ploughs, respectively. Consistent with findings by Kanber (2001), the greatest reductions in infiltration rates were observed when the rotary plough was used. This may be due

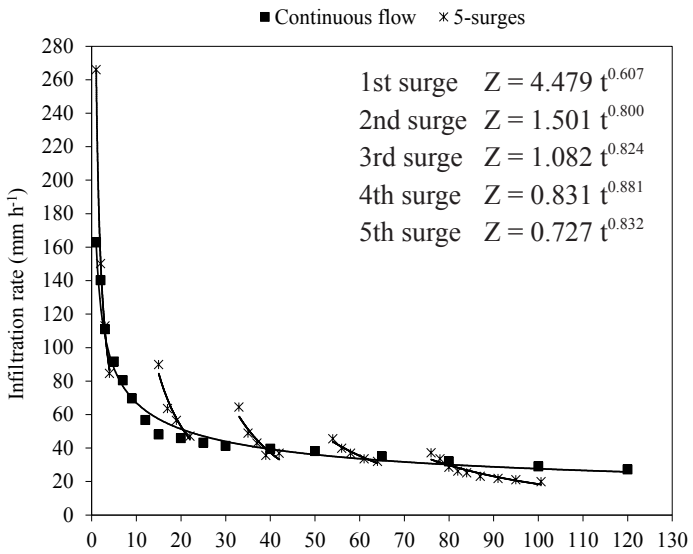

b

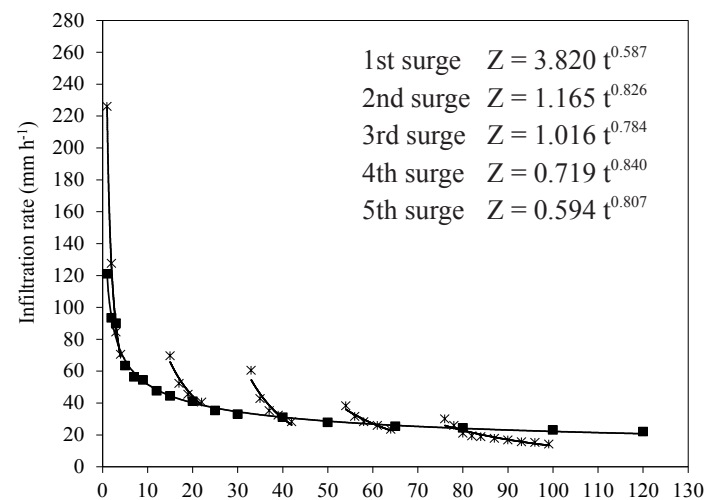

c

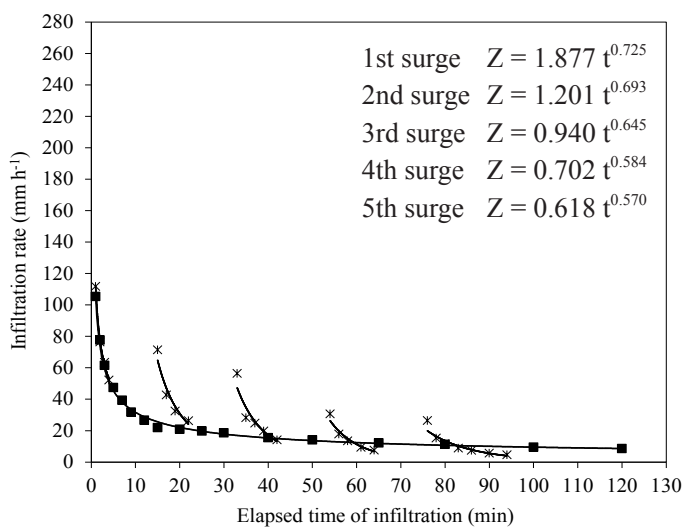

Fig. 4. Comparison of infiltration rates for 5-surges and continuous flow under: $\mathrm{a}$ - moldboard plow, $\mathrm{b}$ - chisel plow, $\mathrm{c}$ - rotary plow.

to the highest bulk density and the lowest total porosity. In most cases, the last infiltration rates measured were lower with surge flow than with continuous flow, despite shorter opportunity times for surge flows. Since infiltration rates became fairly constant by the end of most of the tests, the infiltration rates may be termed quasi-steady. This is in accordance with Bautista and Wallender (1985) and 
a

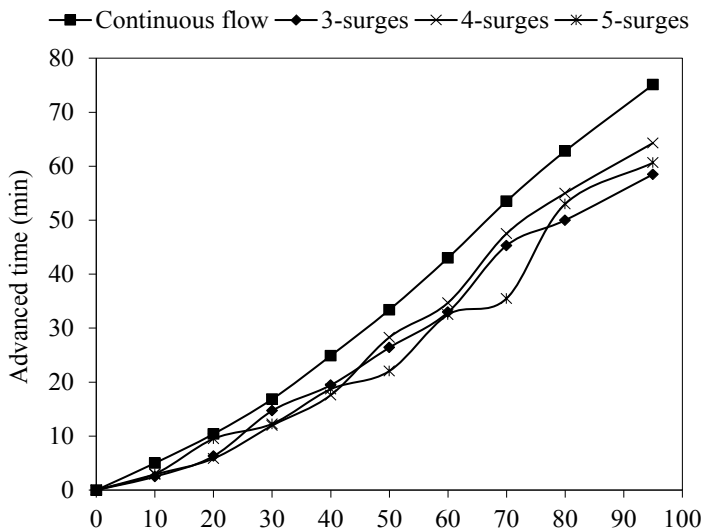

b

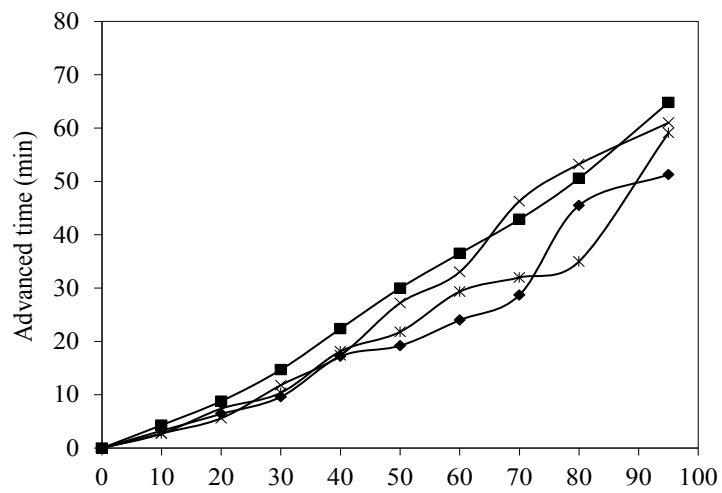

c

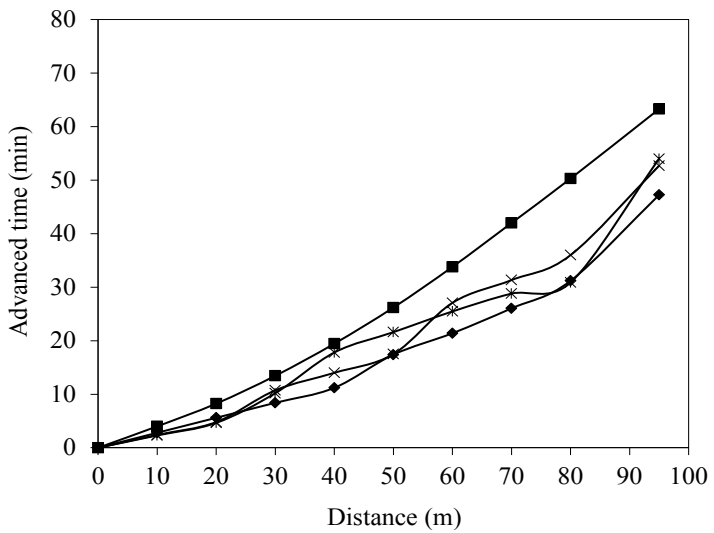

Fig. 5. Average of advance time differences for continuous and surge flow irrigation under: $\mathrm{a}$ - moldboard plow, $\mathrm{b}$ - chisel plow, $\mathrm{c}$ - rotary plow.

Testezlaf et al. (1987). The typical power function that can be characterised by the Kostiakov relationship is fitted in Figs 2 to 4 to the cumulative infiltration data.

The average (first three irrigations) advance time of the different irrigation treatments for the three different tillage systems is illustrated in Fig. 5. The average values of time required for water to advance to the end of the furrow in the continuous flow case were 75.1, 64.8, and $63.3 \mathrm{~min}$ for the mouldboard, chisel, and rotary ploughs, respectively. This indicates that water advance rate was the fastest for the rotary plough. This may be due to the highest bulk density and the lowest total porosity when the rotary plough was used. This is in conformance with Hamad et al. (1992).

For the mouldboard plough, the average values of advance time required for water to reach the end of the furrow for 3-, 4- and 5-surges treatments were 58.50, 64.30 and $60.65 \mathrm{~min}$, respectively (average of $61.15 \mathrm{~min}$ ), as shown in Fig. 5. The corresponding values for the chisel plough were $51.30,61.00$ and $59.10 \mathrm{~min}$ (average of $57.13 \mathrm{~min}$ ); the corresponding values for the rotary plough were 47.25 , 52.70 and $54.00 \mathrm{~min}$ (average of $51.32 \mathrm{~min}$ ).

Therefore, in surge irrigation treatments for mouldboard, chisel and rotary plough conditions, water reached the end of the furrow in $81.42,88.16$ and $81.07 \%$ of the time required for continuous flow treatment, respectively. This means that the surge irrigation treatments saved 18.58, 11.84 and $18.93 \%$ of the time required for the continuous flow treatment to complete the advance phase for the mouldboard, chisel and rotary ploughs, respectively. For each plough system, the 3 -surges treatment had the fastest advance rate. This may be due to a higher off-time between surges that reduced infiltration rate, according to Samani et al. (1985). Generally, the surge flow treatments had a faster advance rate than the continuous ones (Horst et al., 2007; Ismail, 2003; Kanber, 2001; Kifle et al., 2008; Latif and Ittefaq, 1998). This may be attributed to the redistribution of the infiltrated water in the soil profile during the off-time, particle sealing of the wetted soil surface, and the creation of a smooth surface for the next surge (Izadi et al., 1990; Segeren and Trout, 1991; Trout, 1991).

The advance rate data equations for all treatments are tabulated in Table 1. The advance time equations were statistically obtained by regression on the data from the irrigation runs. The coefficient of determination $\left(\mathrm{R}^{2}\right)$ values were generally highly significant. This means that the obtained difference is due to regression, while the deviation from regression (error) is very small in most of them and nothing in the others.

During the growing season there were six irrigations. The total amounts of water applied to the different treatments are given in Table 2. For the mouldboard plough treatments, the table shows considerable reductions in the amount of water applied, 22.10, 14.38 and $19.24 \%$ by using 3-, 4- and 5-surges treatments, respectively, compared with water applied to the continuous flow treatment. The corresponding reductions of the applied water for the chisel plough were $20.83,5.86$ and $8.80 \%$ in 3-, 4- and 5-surges treatments, respectively. Also, for the rotary plough, the corresponding reductions of the applied water were 25.36, 16.75 and $14.69 \%$ in 3-, 4- and 5-surges treatments, respectively. Therefore, the surge flow technique caused a great reduction in the total volume of water used compared to the volume used by the continuous flow technique. The best treatment for reducing applied irrigation water was the 3 -surges treatment with the rotary plough treatment. 
T a b l e 1. Advance equation and total amount of applied water with continuous and surge flow irrigation under three different plows

\begin{tabular}{|c|c|c|c|c|c|c|}
\hline \multirow{2}{*}{ Plow treatments } & \multirow{2}{*}{$\begin{array}{l}\text { Irrigation } \\
\text { treatments }\end{array}$} & \multicolumn{3}{|c|}{ Advance equation $x=p t^{r}$} & \multicolumn{2}{|c|}{ Total amount of applied water } \\
\hline & & $p$ & $r$ & $\mathrm{R}^{2}$ & $\mathrm{~m}^{3} \mathrm{ha}^{-1}$ & $\%$ of continuous \\
\hline \multirow{4}{*}{ Moldboard } & Continuous & 0.269 & 1.236 & 0.997 & 5068.26 & 100 \\
\hline & 3 -surges & 0.095 & 1.434 & 0.993 & 3947.98 & 77.90 \\
\hline & 4-surges & 0.088 & 1.460 & 0.992 & 4339.40 & 85.62 \\
\hline & 5-surges & 0.162 & 1.292 & 0.987 & 4093.07 & 80.76 \\
\hline \multirow{4}{*}{ Chisel } & Continuous & 0.244 & 1.220 & 0.998 & 4373.14 & 100 \\
\hline & 3-surges & 0.165 & 1.240 & 0.982 & 3462.08 & 79.17 \\
\hline & 4-surges & 0.084 & 1.462 & 0.992 & 4116.69 & 94.14 \\
\hline & 5 -surges & 0.141 & 1.294 & 0.989 & 3988.47 & 91.20 \\
\hline \multirow{4}{*}{ Rotary } & Continuous & 0.209 & 1.244 & 0.997 & 4271.92 & 100 \\
\hline & 3 -surges & 0.144 & 1.228 & 0.984 & 3188.75 & 74.64 \\
\hline & 4-surges & 0.092 & 1.372 & 0.991 & 3556.56 & 83.25 \\
\hline & 5-surges & 0.094 & 1.368 & 0.981 & 3644.28 & 85.31 \\
\hline
\end{tabular}

T a b l e 2. Adjusted parameters for the fit of the Kostiakov infiltration equation to surge treatments data $\left(Z^{\prime}=k^{`} T^{a}\right)$ for different tillage systems

\begin{tabular}{|c|c|c|c|c|c|c|}
\hline \multirow{2}{*}{ Treatments } & \multicolumn{2}{|c|}{ Moldboard plow } & \multicolumn{2}{|c|}{ Chisel plow } & \multicolumn{2}{|c|}{ Rotary plow } \\
\hline & $k^{\prime}$ & $a$ & $k^{\prime}$ & $a$ & $k^{\prime}$ & $a$ \\
\hline \multirow{3}{*}{3 -surges } & 10.504 & 0.671 & 10.111 & 0.639 & 7.789 & 0.643 \\
\hline & 0.678 & 0.947 & 0.494 & 0.990 & 1.20891 & 0.814 \\
\hline & 0.559 & 0.951 & 1.079 & 0.917 & 0.640 & 0.749 \\
\hline \multirow{4}{*}{ 4-surges } & 12.638 & 0.645 & 11.163 & 0.627 & 8.834 & 0.631 \\
\hline & 3.439 & 0.846 & 2.660 & 0.854 & 3.918 & 0.646 \\
\hline & 0.843 & 0.890 & 1.296 & 0.902 & 1.273 & 0.653 \\
\hline & 0.729 & 0.862 & 0.875 & 0.763 & 2.400 & 0.571 \\
\hline \multirow{5}{*}{5 -surges } & 13.450 & 0.607 & 14.270 & 0.587 & 9.235 & 0.725 \\
\hline & 3.663 & 0.800 & 1.404 & 0.826 & 5.762 & 0.693 \\
\hline & 1.610 & 0.824 & 2.688 & 0.784 & 1.195 & 0.645 \\
\hline & 2.255 & 0.881 & 0.913 & 0.840 & 0.7640 & 0.584 \\
\hline & 0.846 & 0.832 & 1.183 & 0.807 & 2.842 & 0.570 \\
\hline
\end{tabular}



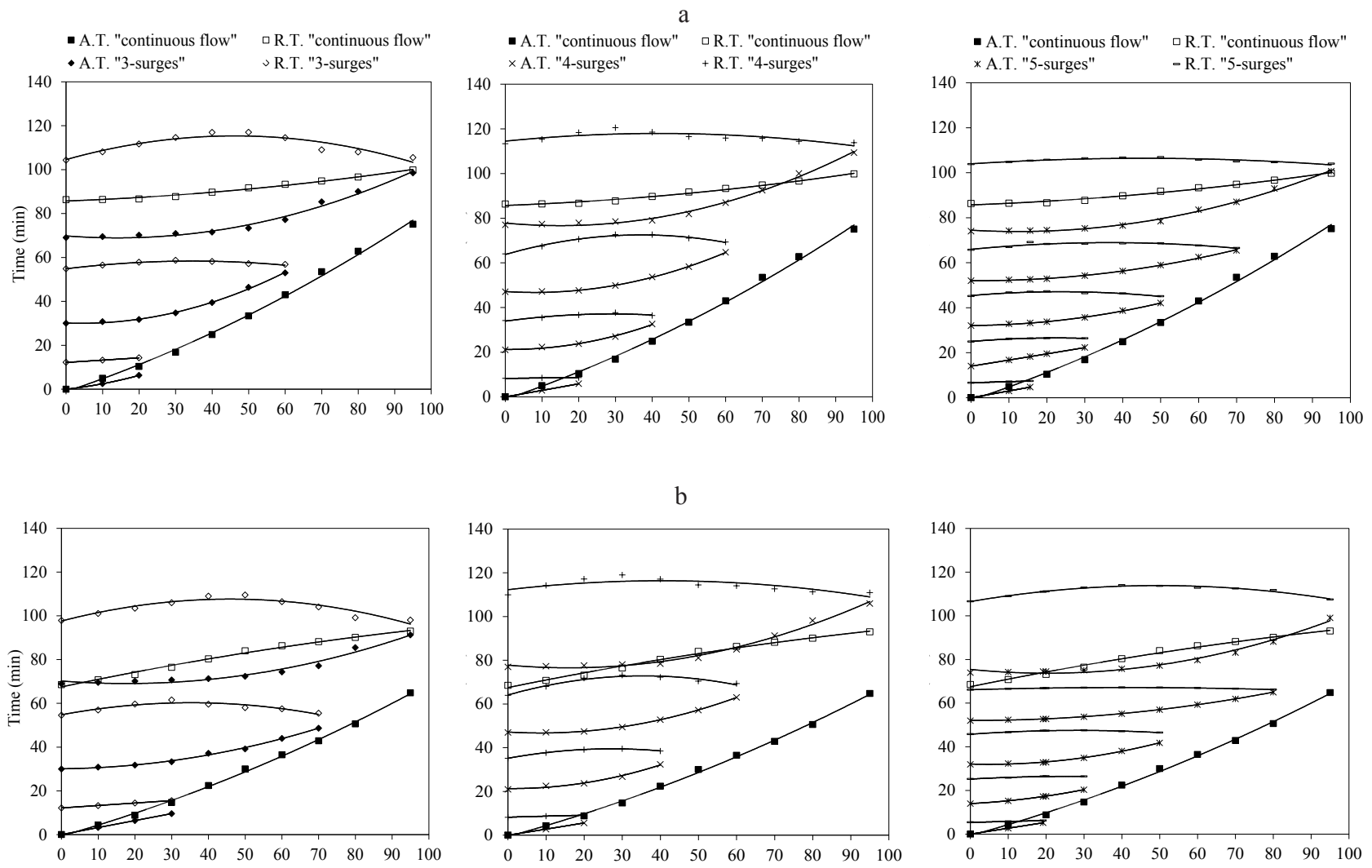

C
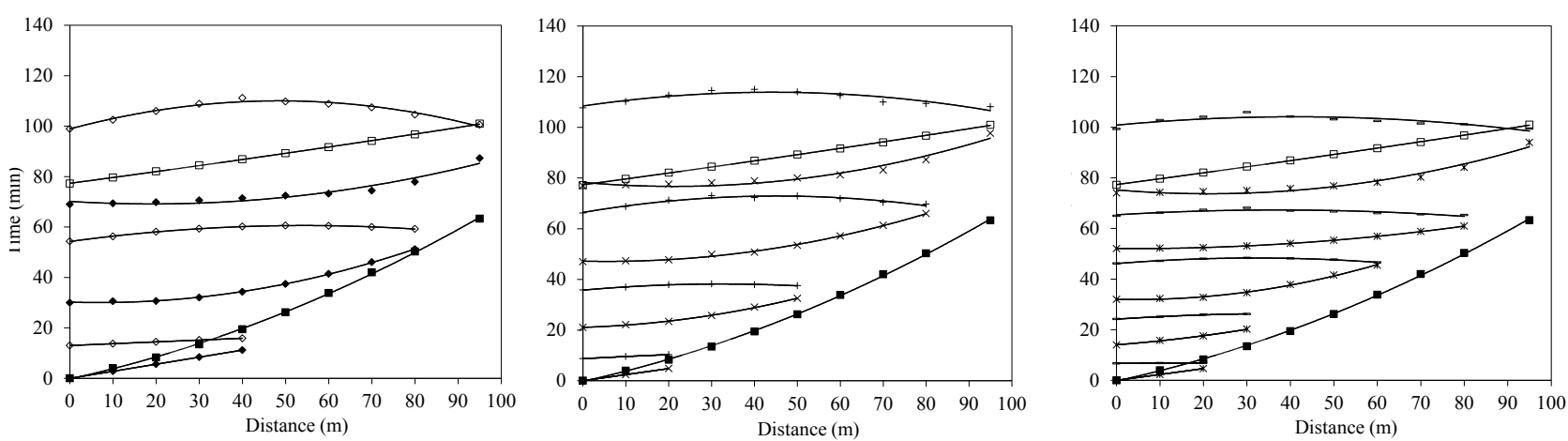

Fig. 6. Comparison of advance (A.T.) and recession (R.T.) times for continuous and surge flow irrigation under: a - moldboard plow, $\mathrm{b}$ - chisel plow, $\mathrm{c}$ - rotary plow.

The continuous infiltration depth at each station on the furrow was calculated by using opportunity times which are calculated as the difference between the advance (A.T.) and recession time (R.T.) as shown in Fig. 6, with the Kostiakov equation for the cumulative infiltration depth (Fig. 1). In Fig. 6, the surge flow treatments showed that the opportunity time was found by measuring the difference between the A.T. and R.T. for each surge. The infiltration depth of the surge flow was found from the typical power function as shown in Figs 2 to 4. In the surge flow treatments, the average typical infiltration depths were compared with the depths of water applied in each surge to check the infiltration depth for each station. Therefore, the coefficient $k$ of the Kostiakov equation was adjusted to become $k$ ' whereas, the exponent constant $a$ remained the same, as presented in Table 2.

In each surge, the adjusted infiltration depth at each station and the average of infiltration depths among the stations were computed as a check for the adjusted equation. The average of the infiltration depths was found to equal the depth of inflow. The adjusted infiltration depths at each 
a

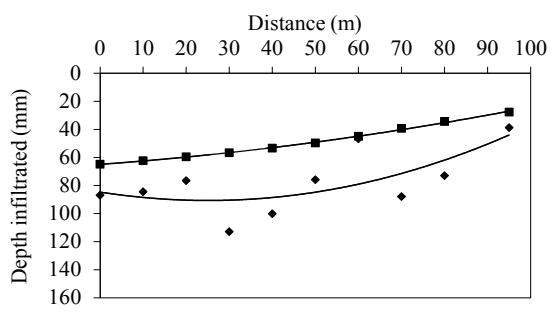

Distance (m)

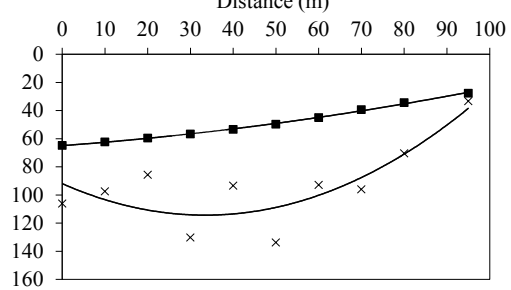

Distance $(\mathrm{m})$

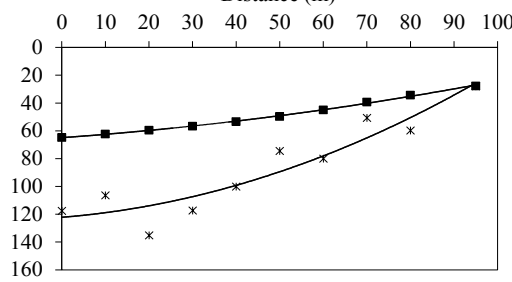

$\mathrm{b}$
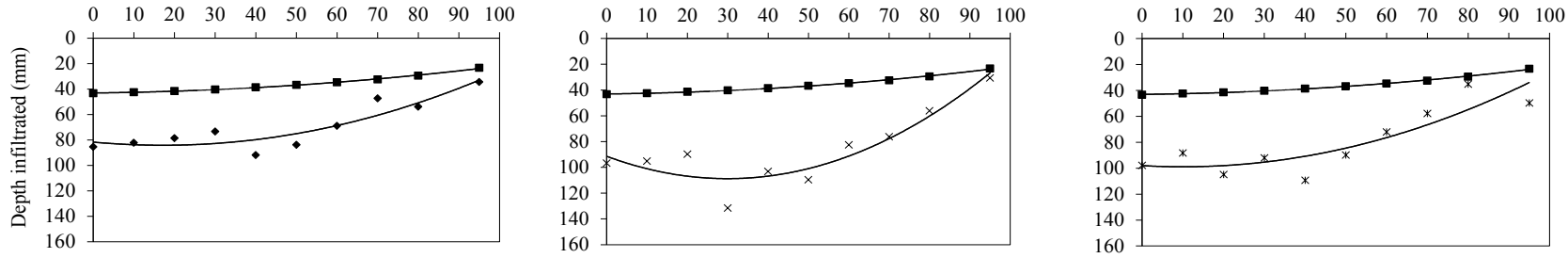

$\mathrm{c}$

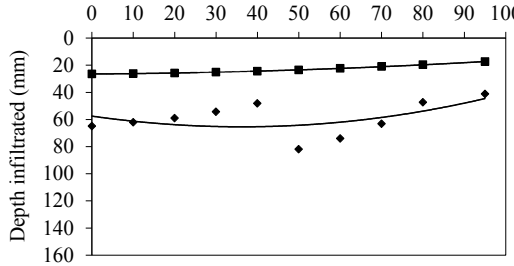

- Continuous flow $\bullet$ - -surges
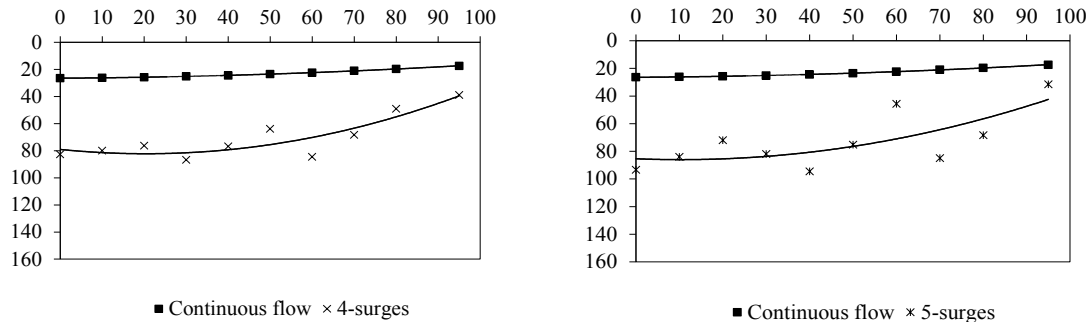

Fig. 7. Infiltrated water distribution curves for continuous and surge flow irrigation under: a - moldboard plow, b - chisel plow, c - rotary plow.
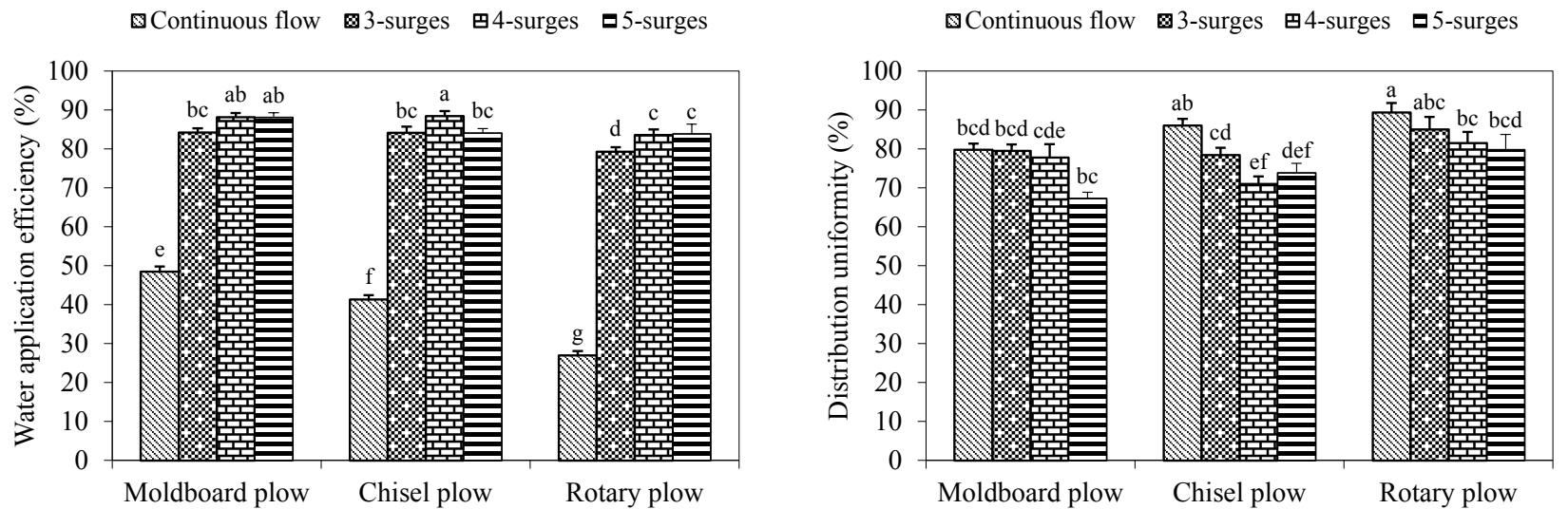

Fig. 8. Water application efficiency and distribution uniformity of continuous and surge flow irrigation under three tillage systems. Different letters on top columns show significant differences between irrigation treatments across tillage systems at 0.05 level of probability $(\mathrm{p}<0.05)$ by the least significant difference (LSD) test. Bars give the means \pm standard error of the mean $(n=3)$. 
T a b l e 3. Analysis of variances on the effect of experimental factors and their interactions on water application efficiency $\left(E_{a}\right)$ and distribution uniformity $(D U)$

\begin{tabular}{lcc}
\hline Factor & $E_{a}$ & $D U$ \\
\hline Tillage systems & & \\
Moldboard & $77.23 \mathrm{a}$ & $76.06 \mathrm{~b}$ \\
Chisel & $74.52 \mathrm{~b}$ & $77.33 \mathrm{~b}$ \\
Rotary & $68.44 \mathrm{c}$ & $83.91 \mathrm{a}$ \\
p-value & $<0.001$ & $<0.001$ \\
LSD 0.05 & 2.09 & 3.70 \\
Irrigation treatment & & \\
Continuous & $38.98 \mathrm{c}$ & $85.05 \mathrm{a}$ \\
3-surges & $82.55 \mathrm{~b}$ & $80.92 \mathrm{ab}$ \\
4-surges & $86.72 \mathrm{a}$ & $76.77 \mathrm{bc}$ \\
5-surges & $85.34 \mathrm{a}$ & $73.67 \mathrm{c}$ \\
p-value & $<0.001$ & $<0.001$ \\
LSD 0.05 & 2.41 & 4.27 \\
Tillage x irrigation & & \\
p-value & $<0.001$ & 0.152 \\
\hline
\end{tabular}

Means followed by the same letters in a column of each experimental factors are not significantly different at $\mathrm{p}<0.05$ according to the LSD test.

location along the furrow are plotted in Fig. 7 and the infiltration depths for continuous flow are drawn in the same figure.

The water application efficiency $\left(E_{a}\right)$ for continuous flow and surge flow treatments under different tillage systems is depicted in Fig. 8. Table 3 shows a summary of the analysis of variance on the $E_{a}$ values across the irrigation treatments and tillage systems. From the analysis, it was found that there were significant differences $(p<0.01)$ between the irrigation treatments. There was a significant $(p<0.01)$ interaction effect between the irrigation treatments and tillage systems for $E_{a}$. Irrespective of the irrigation treatments, significant $(\mathrm{p}<0.01)$ changes in $E_{a}$ between plough treatments were noted. The $E_{a}$ values for continuous flow were 48.51, 41.37 and $27.04 \%$ under mouldboard, chisel and rotary ploughs, respectively. In the 3 -surges treatments, the $E_{a}$ values exceeded continuous flow values by $73.57,103.37$ and $193.31 \%$ for the mouldboard, chisel, and rotary ploughs, respectively. The value of $E_{a}$ for the rotary plough was $5.81 \%$ less than that obtained for the mouldboard plough.
Higher values of $E_{a}$ were obtained by increasing the number of surges from three to four. In the 4-surges treatments, the $E_{a}$ values exceeded continuous flow values by $81.68,113.78$ and $209.02 \%$ for the mouldboard, chisel and rotary ploughs, respectively. Going from four to five surges, there was a decrease in most values of $E_{a}$. In the 5-surges treatments, the $E_{a}$ values for mouldboard, chisel and rotary ploughs were $88.06,84.11$ and $83.86 \%$, respectively. Using 5 -surges with the different tillage systems gave $E_{a}$ values that exceeded continuous flow values by $81.52,103.33$ and $210.15 \%$.

From these calculations, the $E_{a}$ values for surge flow treatments were higher than those for continuous ones. This can be attributed to the rapid advance of the waterfront for surge flow treatments (Ismail et al., 1985, 2004; Kanber, 2001; Kifle et al., 2008). On the other hand, the $E_{a}$ value for the 4-surges treatment with the mouldboard plough was the highest. This might be due to the mouldboard causing lower bulk density and higher total porosity than the others.

The effects of the irrigation treatments and tillage systems on distribution uniformity $(D U)$ are also shown in Fig. 8. Statistically significant differences $(\mathrm{p}<0.01)$ in $D U$ were found between irrigation treatments (Table 3$)$. There was also a significant difference in $D U(\mathrm{p}<0.01)$ between different tillage systems, irrespective of the irrigation treatments. The $D U$ values for continuous flow treatments were $79.41,86.13$ and $89.33 \%$ under mouldboard, chisel and rotary ploughs, respectively. Although continuous flow treatments showed higher $D U$ values for some tillage systems, significant interactions between irrigation treatments and tillage systems $(p>0.05)$ were not observed, as shown in Fig. 8. The values of $D U$ for the surge flow treatments were lower than those for the continuous flow treatments under different tillage systems. This may be because the soil is able to retain a high amount of water. Compared with continuous flow, the $D U$ values for 3 -surges irrigation decreased by $0.35,8.79$ and $4.84 \%$ for the mouldboard, chisel and rotary ploughs, respectively, while the values of $D U$ for 4 -surges were $2.43,17.46$ and $8.73 \%$ lower. The 5-surges treatments had $D U$ values that decreased drastically, and were $15.64,14.11$ and $10.66 \%$ less than those from the continuous flow treatments, for the mouldboard, chisel and rotary ploughs, respectively. Generally, the $D U$ values for the rotary plough were the highest. This may be attributed to the highest bulk density and the lowest total porosity. Also, a trend is observed in Fig. 8; in surge flow treatments, the $D U$ value for the 3-surges treatment with the rotary plough was the highest, due to the highest offtime (20 min). 


\section{CONCLUSIONS}

1. Surge flow treatments required less time to complete the advance phase than continuous flow treatments. Therefore, less water was consumed to achieve a given advance distance. The 3 -surges treatment with the rotary plough had the fastest advance rate.

2. The surge flow caused a reduction in the quasi-steady infiltration rates for the three studied ploughs, despite shorter opportunity times for the surge treatments.

3. Water application efficiency for surge flow treatments gave the highest values, thus indicating good system management compared with continuous flow treatments. On the contrary, distribution uniformity gave the lowest values for surge flow treatments, indicating inappropriate system performance.

4. Future investigations need to study the effects of surge irrigation on advance rates, considering soil type, cross-sectional characteristics of the furrow, longitudinal slope of the furrow, and inflow rates.

Conflict of interest: The Authors do not declare conflict of interest.

\section{ACKNOWLEDGEMENTS}

With sincere respect and gratitude we would like to express deep thanks to the Deanship of Scientific Research, King Saud University and Agriculture Research Center, College of Food and Agriculture Sciences, for financial support, sponsorship, and encouragement.

\section{REFERENCES}

ASABE, 2003. Evaluation of irrigation furrows. EP 419.1. In: ASABE Standards (Ed. M.I. Joseph). ASABE, 919-924

Bautista E. and Wallender W.W., 1985. Spatial variability of infiltration in furrows. Trans. ASABE, 28(6), 1846-1851, 1855.

Bishop A.A., Walker W.R., Allen N.L., and Poole G.J., 1981. Furrow advance rates surge flow systems. J. Irrigation Drainage Division, ASCE, 107 (IR3), 257-264.

Cholpankulov E.D., Inchenkova O.P., Paredes P., and Pereira L.S., 2005. Strategies for irrigation scheduling to cope with water scarcity. In: Irrigation Management for Combating Desertification in the Aral Sea Basin. Assessment and Tools (Eds L.S. Pereira, V.A. Dukhovny, M.G. Horst). Vita Color Publisher, Tashkent, Uzbekistan.

CoStat Version 6.303 Copyright_1998-2004 CoHort Software798 Lighthouse Ave. PMB 320, Monterey, CA, 93940, USA.

Eid S.I., 1998. Surge flow irrigation for corn and wheat under different land levelling practices in heavy clay soils. Ph.D. Thesis, Department of Soil Science, Faculty of Agriculture, Kafr El-Sheikh, Tanta University, Egypt.

El-Biely M.M., 1995. Effect of ploughing operation on soil physical properties. M.Sc. Thesis, Department of Agricutlural Engineering, Faculty of Agriculture, Kafr El-Sheikh, Tanta University, Egypt.
El-Gohary E.A.A., Saffan M.M., and Ibrahim M.A.M., 1988. Effect of different types of ploughs on some soil physical properties, growth, yield and yield component. J. Agric. Res. Tanta University, 14(1), 431-438.

El-Zaher H., Osman A.M., Attia M.M., and Said M.S., 1996. Surge flow furrow irrigation in calcareous soil, 2- water application and water use efficiencies and productivity of faba bean. J. Agric. Sc. Mansoura Univ., 21(10), 3679-3686.

Hamad S.A., AbdelMageed H.N., and ElKagaga B., 1992. Effect of tillage methods on soil physical characteristics and corn yield. Misr J. Agric. Eng., 9(1), 32-42.

Horst M.G., Shamutalov S.S., Gonçalves J.M., and Pereira L.S., 2007. Assessing impacts of surge-flow irrigation on water saving and productivity of cotton. Agric. Water Manag., 87, 115-127.

Horst M.G., Shamutalov S.S., Pereira L.S., and Gonçalves J.M., 2005. Field assessment of the water saving potential with furrow irrigation in Fergana, Aral Sea Basin. Agric. Water Manag., 77, 210-231.

Ismail S.M., 2003. Surge flow irrigation: field experiments under short field conditions in Egypt. Workshop on improved irrigation technologies and methods: R\&D and testing. In: Proc. 54th executive council of ICID and 20th European regional conference, September 14-19, Montpellier, France.

Ismail S.M., Depewege H., and Schultz B., 2004. Surge flow irrigation under short field conditions in Egypt. Irrig. Drain., 53, 461-475.

Ismail S.M., Westesen G.L., and Larsen W.E., 1985. Surge flow border irrigation using an automatic drop gate. Trans. ASABE, 28(2), 532-536.

Izadi B., Studer D., and McCann I.R., 1991. Maximizing setwide furrow irrigation application efficiency under full irrigation strategy. Trans. ASABE, 34(5), 2006-2014.

Izuno F.T., Podmore T.H., and Duke H.R., 1985. Infiltration under surge irrigation. Trans. ASABE, 28(2), 517-521.

Jalali-Farahani H.R., Duke H.R., and Heerman D.F., 1998. Physics of surge flow irrigation. Trans. ASABE, 36(1), 37-44.

James L.G., 1993. Principles of farm irrigation system design. Krieger Publishing Company, 73, 152-153.

Kanber R., Köksal H., Önder S., Kapur S., and Sahan S., 2001. Comparison of surge and continuous furrow methods for cotton in the Harran plain. Agric. Water Manag., 47, 119-135.

Kemper W.D., Trout T.J., Hampherys A.S., and Bullock M.S., 1988. Mechanisms by which surge irrigation reduces furrow infiltration rates in silt loam soil. Trans. ASABE, 31(3), 821-829.

Kifle M., Tilahun K., and Yazew E., 2008. Evaluation of surge flow furrow irrigation for onion production in a semiarid region of Ethiopia. Irrig Sci., 26, 325-333.

Latif M. and Ittfaq M., 1998. Performance of surge and continuous furrow irrigations. Rural Environ. Eng., 34(2), 35-42.

Michael A.M., 1978. Irrigation theory and practice. New Delhi, 546-603.

Osman A.M., 1991. Surge flow irrigation for corn and faba bean in clay soil. Ph.D. Thesis, Department of Soil Science, Faculty of Agriculture, Alexandria University, Egypt.

Purkey D.R. and Wallender W.W., 1989. Surge flow infiltration variability. Trans. ASAE, 32(3), 894-900. 
Samani A.Z., Walker W.R., and Willardson L.S., 1985. Infiltration under surge flow irrigation. Trans. ASABE, 28(5), 1539-1542.

Segeren A.G. and Trout T., 1991. Hydraulic resistance of soil surface seals in irrigated furrows. Soil Sci. Soc. Am. J., 55(3), 640-646.

Stringham G.E. and Keller J., 1979. Surge flow for automatic irrigation. Proc. ASCE Irrigation and Drainage Division Specialty Conf., Albuquerque, New Mexico.

Suliman A.E., Nasr G.M., and Adawy W.I., 1993. A study on the effect of different systems of tillage on the physical properties of the soil. Misr. J. Agric. Eng., 10(2), 169-189.

Taieb A.Z., 1998. Effect of different tillage methods on some physical properties soil and sunflower yield. Misr. J. Agric. Eng., 15(1), 159-173.
Testezlaf R., Elliott R.L., and Garton J.E., 1987. Furrow infiltration under surge flow irrigation. Trans. ASABE, 30(1), 193-197.

Trout T.J., 1991. Surface seal influence on surge flow furrow infiltration. Trans. ASABE, 34(1), 66-72.

Walker W.R., 1989. Guidelines for designing and evaluating surface irrigation systems. Irrigation and Drainage paper 45, FAO, Rome, Italy.

Walker W.R., Prestwich C., and Spofford T., 2006. Development of the revised USDA-NRCS intake families for surface irrigation. Agric. Water Manag., 85, 157-164.

Wang W., Luo W., and Wang Z., 2005. Surge flow irrigation with sediment-laden water in northwestern China. Agric. Water Manag., 75, 1-9.

Younts C.D., Elsenhauor D.E., and Fekersillassie D., 1996. Impact of surge irrigation on furrow water advance. Trans. ASABE, 39(3), 973-979. 